\title{
Rescue and relocation programme of turtles and tortoises and elongated tortoise monitoring programme in the Nam Theun 2 Reservoir (Laos)
}

\author{
Programme de collecte et de translocation des tortues et suivi \\ des populations de tortues à tête jaune au niveau du Réservoir \\ Nam Theun 2 (Laos)
}

\author{
S. Som ${ }^{(1)}$, M. $\operatorname{Cottet}^{(2)}$ \\ (1) Consultant for Nam Theun 2 Power Company, \# 216H, Street 63, Boeng Keng Kang I, Chamkarmorn, \\ Phnom Penh, Cambodia \\ sithasom@yahoo.com \\ (2) Nam Theun 2 Power Company Limited (NTPC), Environment \& Social Division - Water Quality \\ and Biodiversity Dept. - Gnommalath Office, PO Box 5862, Vientiane, Lao PDR
}

\begin{abstract}
The impoundment of the Nam Theun 2 (NT2) Reservoir on the Nakai Plateau resulted in the creation of a $489 \mathrm{~km}^{2}$ reservoir at its full supply level. This inundation has generated a modification of the environment e.g. in terms of geomorphology especially for the wetlands and terrestrial ecosystems. Wildlife population including six species of fresh water turtles and tortoises has been expected to be affected by the NT2 Reservoir impoundment. In order to avoid an excessive loss of these populations, a turtle conservation programme (rescue, relocation, and monitoring programmes) was conducted with two distinct phases (i) the first phase started before the reservoir impoundment (January 2008) and ended after the reservoir reached its full supply level (January 2009) and (ii) the second phase (monitoring only) was conducted from August 2008 to January 2009 and from November to December 2009. A total of 490 individuals belonging to four freshwater turtle species and three terrestrial species were rescued and relocated into different selected habitats above the full supply level. This number of rescued individuals exceeded the objectives of the rescue and relocation programme. The monitoring programme's results focused particularly on nine individuals belonging to the elongated tortoise species (Indotestudo elongata). Results showed all nine observed elongated tortoises were successfully surviving. However their annual survival rate declined from $100 \%$ during the first phase of the programme to $47 \%$ after the two monitoring phases. This annual apparent survival rate was outside the range of the natural annual survival rate of this species ( $88 \%$ to $96 \%$ ). However, the programme found that this sharp decline might be caused by either an error of transmitters attached on individuals or external threats from poaching. This hypothesis was supported by the fact that the four individuals re-tracked showed good sign of population establishment (e.g. normal increase in body weight).
\end{abstract}


Key words - Key words. - reservoir, freshwater and terrestrial turtle and tortoise, monitoring, Indotestudo elongata

Résumé - La mise en eau du réservoir de Nam Theun 2 (NT2) sur le plateau de Nakai a entraîné la création d'un réservoir d'environ $489 \mathrm{~km}^{2}$ à son plus haut niveau. Cette mise en eau a engendré une modification de l'environnement, par exemple en termes de géomorphologie notamment pour les zones humides et les écosystèmes terrestres. Ainsi, il était prévisible que la faune sauvage dont six espèces de tortues d'eau douce et terrestres soit affectée par la mise en eau du réservoir NT2. Afin d'éviter une trop grande diminution de ces populations, un programme de conservation des tortues (programmes de collecte, de translocation et de surveillance) a été conduit selon deux phases distinctes : (i) la première phase a débuté avant la mise en eau (janvier 2008) et se termina après que le réservoir ait atteint son niveau le plus haut (janvier 2009) et (ii) la deuxième phase (programme de surveillance seulement) a été réalisée d'août 2008 à janvier 2009 et en novembre et décembre 2009. Un total de 490 individus, appartenant à quatre espèces de tortues d'eau douce et trois espèces terrestres, ont été collectés et replacés dans différents habitats sélectionnés se situant audessus du niveau le plus haut du réservoir. Ce nombre d'individus récupérés s'est avéré audelà des objectifs fixés lors du programme de collecte et de translocation. Les résultats du programme de surveillance portent plus particulièrement sur le suivi de neuf individus de tortues à tête jaune (Indotestudo elongata). Les résultats ont montré que les neuf individus ont survécu avec succès. Cependant, leur taux annuel de survie de $100 \%$ durant la première phase du programme est passé à $47 \%$ après les deux phases du suivi. Ce taux annuel de survie apparente était en dehors des taux annuels de survie en milieu naturel connus pour cette espèce ( $88 \%$ à $96 \%$ ). Cependant, le programme a permis de constater que cette forte baisse pouvait être causée soit par une erreur des émetteurs attachés aux individus, soit par des menaces externes telles que le braconnage. Cette hypothèse a été confortée par le fait que les quatre individus resuivis ont montré de bon signes d'établissement des populations (e.g. augmentation normale du poids).

Mots clés - réservoir, tortues d'eau douce et terrestres, monitoring, Indotestudo elongata

\section{INTRODUCTION}

Tortoises and turtles are considered as key species within biodiversity components of the ecosystems. They play an important role as keystone species from which other animals and plants benefit within the web of interacting and co-dependent species that occur in a healthy functioning ecosystem (Turtle Conservation Fund, 2002). To date, there are more than 317 species of tortoises and freshwater turtles globally (Buhlmann et al., 2009), and up to
460 species if their sub-species are included (Turtle Conservation Fund, 2002). Asian nations are found to have rich and abundant population of these species.

Global and empirical evidences suggest that no freshwater turtles and tortoises are safe from extinction. According to the IUCN Red List assessment, $63 \%$ of them are considered threatened, and $10 \%$ are critically endangered (Buhlmann et al., 2009). In Asia, the number of freshwater turtles classified as critically endangered in Asia had 
sharply increased from 5 species in 1996 to 19 species in 2003 in IUCN Red List.

Dudgeon et al. (2006) suggest that one of major threats to dramatic population decline is due to the loss of the habitats of the tortoise and turtle species, especially the wetlands. For instance, the Mekong River Commission (MRC) estimated that more than $70 \%$ of the total existing, under construction and potential projects in the Lower Mekong Basin are located in Laos (MRC, 2010). Developing such projects are recognized to be responsible for environmental and biodiversity changes. The construction of reservoir always creates a number of environmental changes such as natural habitat losses and significant alteration in biodiversity including wild terrestrial and aquatic animals (e.g. fish, macroinvertebrates), and changes in water quality (Alho, 2011; McAllister et al., 2001). Consequently, turtles and tortoises communities are negatively affected. Therefore, changes in turtle species composition may occur with, in worse cases, death of individuals (Santucci et al., 2005). Other main threats are illegal hunting for consumption and traditional medicine. For instance, turtles and tortoises in Laos have been traded throughout the country exporting from rural villages in Laos to Vietnam and then China (Le, 2009; Zhou \& Jiang, 2008) to support traditional medicine or have been hunted for local consumption and subsistence (Stuart \& Timmins, 2000). Until recently, half of the Asian tortoises and freshwater turtles have been endangered or critically endangered, primarily due to overexploitation for food and traditional medicine (Stuart \& Thorbiarnarson, 2003).
Among the 90 species known in South Asia, East Asia, Southeast Asia, and New Guinea, 15 freshwater and terrestrial turtles and tortoises have been confirmed in Laos (Stuart \& Timmins, 2000), in which two additional species were confirmed in 2011 (Stuart et al., 2011). The majority of these species are considered as endangered or vulnerable species (Tab. I). However, other species might be present in Laos due to observation in local markets (Som, 2009). These species belong to the Chinese Three-striped box turtle (Cuora trifasciata) and Black marsh turtle (Siebenrockiella crassicollis) (Stuart \& Timmins, 2000) and two introduced species of Chinese soft-shell turtle (Pelodicus sinensis) and Red-eared slider turtle (Trachemys scripta elegans). In 2007, a baseline survey was conducted in view to state on turtle and tortoise population in the Nam Theun 2 (NT2) Project area before the impoundment of the reservoir. This baseline revealed the presence of six species, qualified as a high biodiversity importance (Tab. I) (Bryan, 1999; Stuart \& Platt, 2004), among the 15 presented in Laos from which three endangered species were found to inhabit in the predicted reservoir impoundment area.

Scarce programmes exist for the conservation of reptiles during reservoir creation. Measure of wildlife conservation such as relocation or translocation is known to be a very successful method for mammalian and avian species (Farnsworth \& Seigel, 2013). Concerning reptiles and specifically turtles and tortoises, Ashton \& Burke (2007) found a relatively successful rate of healthy population of gopher tortoises in Florida (USA) through many years of studies on 
Table I. List of turtles and tortoises in Laos and targeted/released species in the Nam Theun 2 area. Tableau I. Liste des tortues d'eau douce et terrestres au Laos et liste des espèces ciblées et relâchées dans la zone de Nam Theun 2.

\begin{tabular}{|c|c|c|c|c|c|}
\hline Scientific name & Common name & Habitat & \begin{tabular}{|l|} 
IUCN \\
Status \\
\end{tabular} & \begin{tabular}{|l|} 
Program \\
me target
\end{tabular} & $\begin{array}{l}\text { Number of captured and } \\
\text { released individuals }\end{array}$ \\
\hline $\begin{array}{l}\text { Platysternon } \\
\text { megacephalum }\end{array}$ & Big-headed turtle & Freshwater & EN & & \\
\hline Cuora amboinensis $^{*}$ & $\begin{array}{l}\text { Southeast Asian } \\
\text { box turtle }\end{array}$ & Freshwater & VU & 50 & 76 \\
\hline Cuora galbinifrons ${ }^{\star}$ & $\begin{array}{l}\text { Indochinese box } \\
\text { turtle }\end{array}$ & Terrestrial & CR & 0 & $5^{* *}$ \\
\hline Cuora bourreti & \begin{tabular}{|l} 
Bourret's box \\
turtle
\end{tabular} & Terrestrial & EN & & \\
\hline Cyclemys oldhamii ${ }^{*}$ & Asian leaf turtle & Freshwater & NT & 200 & 205 \\
\hline Heosemys grandis & $\begin{array}{l}\text { Asian giant pond } \\
\text { turtle }\end{array}$ & Freshwater & VU & 10 & 0 \\
\hline Heosemys annandalii ${ }^{*}$ & $\begin{array}{l}\text { Yellow-headed } \\
\text { temple turtle }\end{array}$ & Freshwater & EN & 0 & $15^{* *}$ \\
\hline Malayemys subtrijuga & $\begin{array}{l}\text { Malayan snail- } \\
\text { eating turtle }\end{array}$ & Freshwater & VU & & \\
\hline Pyxidea mouhotii & Keeled box turtle & Terrestrial & EN & & \\
\hline Sacalia quadriocellata $^{*}$ & Four-eyed turtle & Freshwater & EN & & \\
\hline Amyda cartilaginea* & $\begin{array}{l}\text { Southeast Asian } \\
\text { softshell }\end{array}$ & Freshwater & VU & 75 & 13 \\
\hline Pelochelvs cantorii & $\begin{array}{l}\text { Asian giant } \\
\text { softshell turtle }\end{array}$ & Freshwater & EN & & \\
\hline Indotestudo elongata* & $\begin{array}{l}\text { Elongated } \\
\text { tortoise }\end{array}$ & Terrestrial & EN & 75 & 175 \\
\hline Manouria impressa & $\begin{array}{l}\text { Impressed } \\
\text { tortoise }\end{array}$ & Terrestrial & VU & 0 & $1^{* *}$ \\
\hline Geoemyda spengleri & $\begin{array}{l}\text { Black-breasted } \\
\text { hill turtle }\end{array}$ & Terrestrial & EN & & \\
\hline
\end{tabular}

Note: ${ }^{*}$ is species confirmed to be in Nakai Plateau. ${ }^{\star *}$ not targeted species.

$\mathrm{NE}=$ near-extinction, $\mathrm{CR}=$ critically endangered, $\mathrm{EN}=$ endangered, $\mathrm{VU}=$ vulnerable ,

$\mathrm{NT}=$ near-threatened.

the relocation of this species into a new habitat. However, most projects that tried to involve conservation strategies such as relocations and translocations (RRT) for both amphibians and reptiles have not so far shown enough success to be considered as conservation techniques and mitigation practices (Dodd \& Seigel, 1991).
In this context of biodiversity conservation interest and monitoring, a programme of turtle and tortoise (turtle conservation programme) was implemented in the NT2 hydropower project area (Laos). The preliminary survey conducted by Emmett (2007) underlined that the creation of this new reservoir could result in the local extinction of several 


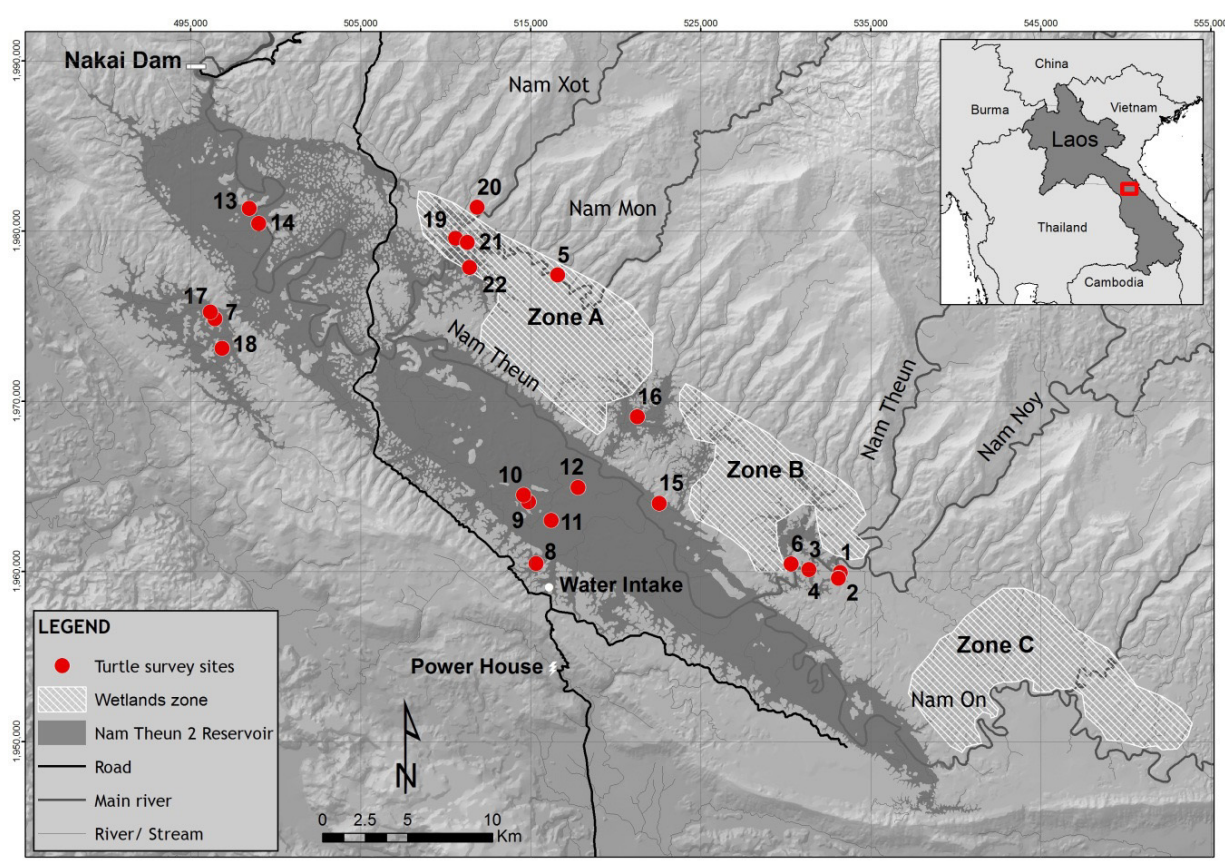

Fig. 1. Map of Nam Theun 2 reservoir area at full supply level with turtle trapping sites.

Fig. 1. Carte du Réservoir Nam Theun 2 à son niveau le plus haut localisant les sites de piégeage des tortues.

freshwater turtle and tortoise species, unless mitigation measures are taken into account. The finding of the baseline survey further suggested that a possibility of saving these turtle and tortoise species from extirpation was by relocating and translocating them into new habitats in the protected area. In this sense, the objectives of the programme implemented in NT2 Project area were: (i) to rescue freshwater and terrestrial turtles and tortoises from the inundated reservoir during and immediately after the impoundment, (ii) to relocate the rescued individuals into suitable habitats, (iii) and to evaluate the adaptation ability and the behaviour of the elongated tortoise (I. elongata) after its relocation.

\section{MATERIAL AND METHODS}

\subsection{Study area}

The Nam Theun 2 (NT2) Reservoir (Khammouane Province, Nakai Plateau, Laos) was filled during the wet season 2008 for hydropower purpose. Commercial operation started in April 2010. At full supply level (FSL) the reservoir represents a surface of $489 \mathrm{~km}^{2}$ (Fig. 1). Its level could reach a potential minimum surface of $86 \mathrm{~km}^{2}$ leading to the formation of a large drawdown areas during the dry season. The NT2 reservoir is considered as a shallow reservoir with a depth average of $8 \mathrm{~m}$ (Chanudet et al., same issue). The 
main tributaries of the NT2 Reservoir are the Nam On, Nam Theun and Nam Xot Rivers. The climate is moist sub-tropical with a warm-wet season (June to October), a cool-dry season (November to February) and a warmdry season (March to May).

The northern shore of the NT2 Reservoir has been qualified as a National Protected Area for a biodiversity conservation purpose. In this area, mainly composed by dense forest, numerous small artificial wetlands were created prior to the impoundment in locations above the potential future full supply level to compensate the habitat loss, linked to the reservoir impoundment. Some vegetation was planted around wetlands dykes and edges to provide microhabitats for species establishment (e.g. for the wildlife monitoring program; Streicher (same issue) and turtle and tortoise conservation programme). These wetlands, divided into different zones (Fig. 1) benefited of a revegetation and soils (unpublished data, Lao MDC Co. Ltd and international wetland and biology specialists). Finally, a water quality monitoring was conducted in the Nam Theun 2 area (Chanudet et al., same issue). The main features and monitoring programmes are described in Descloux et al. (same issue).

\subsection{Main schedule of the turtle conservation programme}

The conservation programme included freshwater turtle, defined as turtle species that live both on land and in water, and terrestrial tortoise, defined as turtle or tortoise species that live only on land.
The programme was divided in two phases:

i) The first phase was conducted from January 2008 (before the Reservoir impoundment) until January 2009 after the reservoir reached its full supply level. This first phase consisted of capturing freshwater turtles and tortoises from the supposed inundated reservoir and releasing them into identified and suitable artificial wetlands or natural habitats. A monitoring programme was also conducted using Radio Telemetry to track the movements, behaviour and adaptation of the elongated tortoise I. elongata.

ii) The second phase (monitoring only) was conducted from November 2009 to December 2009 in view of re-tracking and recapturing the elongated tortoises from the released habitats and finding out their adaptation in the new habitats.

\subsection{Freshwater turtle captures}

Ninety live-capture turtle traps with different designs were used to catch freshwater hard and soft-shell turtles. These freshwater turtles include Amyda cartilaginea, Cyclemys oldhamii, Heosemys annandalii, Cuora amboinensis, and Sacalia quadriocella. These large numbers of traps were used in view to catch as many turtles as possible in each surveyed site. The traps were designed with different entrances and dimensions in view to be placed at different places and water depths (Som et al., 2005).

All traps were baited with strongsmelling baits to attract turtles including chicken meat, buffalo skin, and fruits 
(e.g., pineapple, coconut, jackfruit, papaya, and banana) depending on the food preference of each species (Stuart et al., 2001). All traps were placed into the water with one third of the trap above water surface to allow trapped turtles to reach the surface to breathe. Traps were tied to a nearby tree or wooden pole to prevent the water current or large turtles from pulling them into the water. The team tied a piece of a red tape at each position of the traps to help the team recognising the trap's location. All traps were checked every morning and evening in the case of raining to ensure that traps were not flooded and to avoid drowning turtles (Frazer et al., 1990; Som et al., 2005).

\subsection{Terrestrial turtle and tortoise captures}

To catch terrestrial turtles and tortoises, including the elongated tortoise, the method consisted of using two local dogs and eight team members for all the surveyed sites to have accuracy of searching efforts. The survey consisted of searching in the forest areas and in vegetation alongside streams concealing turtles and tortoises. Finding terrestrial tortoises in the wild is challenging and time consuming because their natural camouflaging colour to their living habitat making them undetectable in the wild to the naked eyes. Therefore, dogs were chosen for their ability to sniff out concealed turtles and tortoises. This method has been used worldwide by many researchers (Som et al., 2005; Cablk \& Heaton, 2006). Surveys were conducted in the forest around each aquatic turtle trapping site. Searches were conducted during daytime from morning to late afternoon when turtles and tortoises were actively feeding (Stuart et al., 2001; Som et al., 2005). The numbers of searching days were dependent on the size of each surveyed site. For example, some searching survey could be conducted only during two hours for a small size site caused by increasing level of reservoir water. Some other sites were conducted up to two days when reservoir water was not yet come up.

\subsection{Trapping and released sites}

A total of 22 sites including streams, rivers, and wetlands were chosen for turtle trapping (Fig. 1). The team also conducted a large proportion of the reservoir covering forest and grassland before and after they were transformed into islands by the reservoir impoundment. These terrestrial surveys aimed to catch terrestrial turtles and tortoises and relocate them onto a new identified habitat in the national protected area. These habitats were divided into three categories (i) wetlands, (ii) rivers, and (iii) terrestrial habitats.

\subsubsection{Wetlands}

Prior to the turtle relocation programme, a number of wetlands were identified to be potentially suitable for the release (Fig. 1). A total of 17 wetlands (Fig. 2) were selected for releasing freshwater turtles. Other wetlands were classified unsuitable habitats for turtles during the initial habitat identification. The only three out of four freshwater turtle species found during the rescue programme were released into these 17 habitats. These species were 


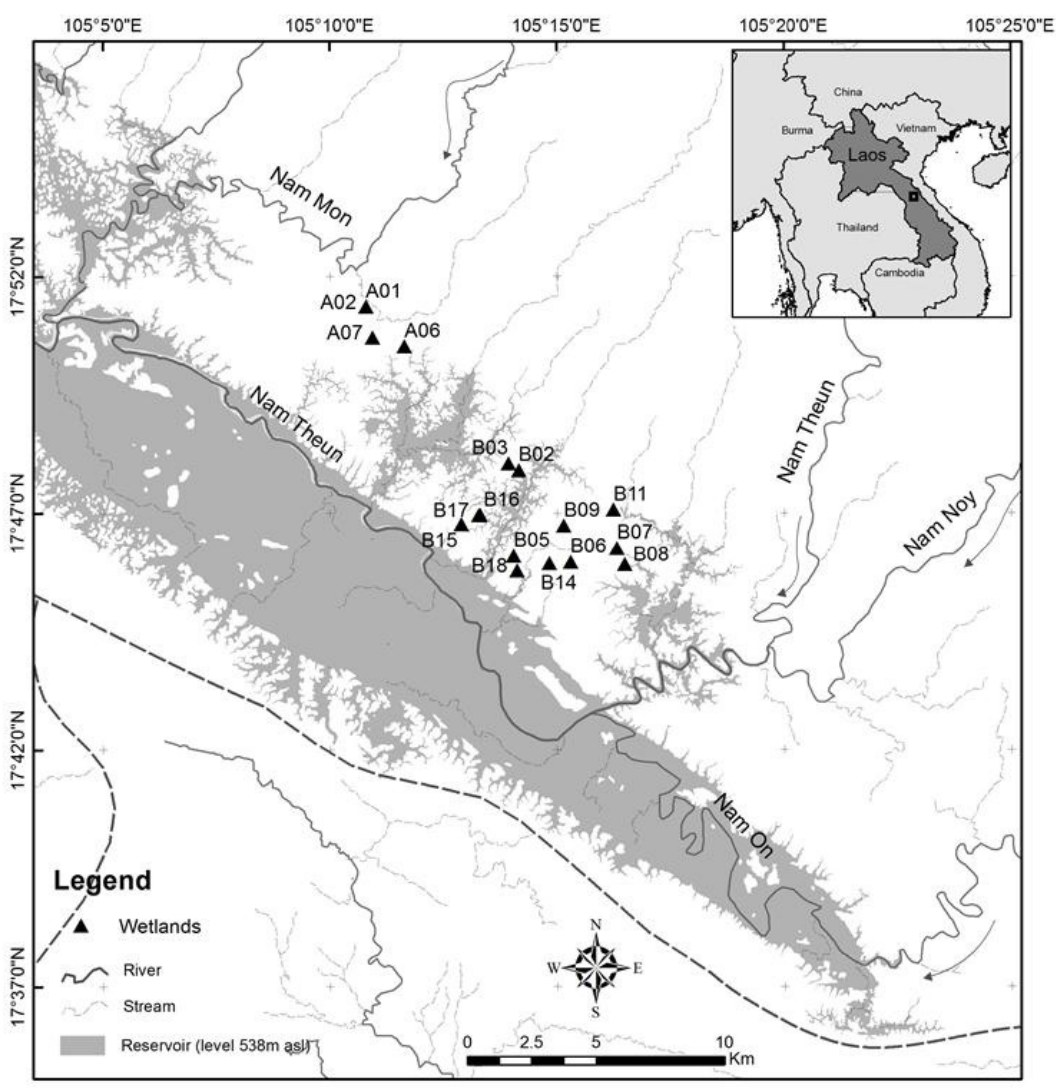

Fig. 2. Map of wetlands where turtles were released.

Fig. 2. Carte des zones humides où les tortues ont été relâchées.

H. annandalii, C. amboinensis, and C. oldhamii. The species Sacalia quadriocellata was not caught during the programme.

\subsubsection{Rivers}

Two rivers were selected for releasing a freshwater soft-shell turtle species of $A$. cartilaginea. These rivers are the Nam Xot River and the Nam Noy River, a tributary of the Nam Theun River
(Fig. 1). The release sites were chosen outside of the reservoir backwater effects and in suitable habitat for this species as these sites have deep pools, rocky areas, sandy beaches, and surrounded by forest vegetation (Stuart et al., 2001).

\subsubsection{Terrestrial habitats}

Two locations of semi-evergreen forest and grassland were selected in 
b

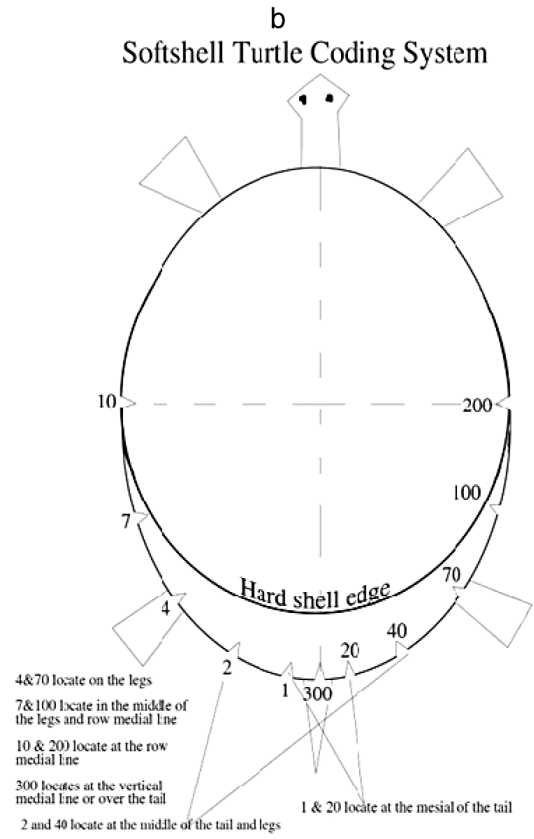

Fig. 3. Marking systems for hard and soft shell turtles (Som et al., 2005).

Fig. 3. Système de marquage des tortues à carapace dure et molle (Som et al., 2005).

Zone A and Zone B (Fig. 1) for releasing I. elongata. These locations were identified during preliminary habitat surveys. One evergreen forest habitat was selected for releasing $C$. galbinifrons. This terrestrial species inhabits only on mountainous evergreen forest. This selected habitat is suitable for this species because they are full of low vegetation as well as bamboo bushes (Stuart \& Parham, 2003).

\subsection{Biological metrics}

Every hard shell turtle and tortoise caught were marked using an internationally-recognized marking system (Fig. 3a) which is used throughout most
Asian countries. A new designed coding system was also used as a marking method to notch soft-shell turtles (Fig. 3b). All turtles were identified by the team using the photographic guide to the turtles of Thailand, Laos, Vietnam and Cambodia (Stuart et al., 2001). Furthermore, all captured turtles were measured both in length (in $\mathrm{cm}$ ) of the carapace and plastron, weighed (in $\mathrm{kg}$ ), aged (years), and sexed.

The behaviour of each individual e.g. swimming, resting, combatting have also been recorded. Furthermore, each species was carefully coded and pictures were taken of their plastron, carapace, teeth, head and tail as proof of captures and sex for each species. 


\subsection{Monitoring programme of the elongated tortoise}

A radio tracking programme was implemented with the endangered elongated tortoise species $I$. elongata, which was released during the relocation programme. This programme was conducted during two periods:

i) during the relocation programme after the first released individuals from August 2008 until January 2009,

ii) secondly from November to December 2009.

Nine adult elongated tortoises were fitted with transmitters and tracked weekly during the first phase of the monitoring and only one tracking occasion was done during the second phase of the monitoring due to the time constraint. The programme aims to evaluate their adaptation after relocation into the new habitats by tracking their movements, feeding behaviour, and vegetation preferences. This programme was implemented to recapture the species and evaluate its physical condition. An ATS FM16 fieldmaster receiver (advanced telemetry systems) was used during the programme. All transmitters on each tortoise were channelled in relation to each tortoise identity (ID). SPARKO glue manufactured by SPARKO USA Inc. and propoxy glue manufactured by HERCULES Company were used for attaching the transmitters to the tortoise shells. Thermohygrometer model data loggers were used to measure humidity and temperature of each individual at the place of each individual found during tracking. All procedures were followed in accordance with Goodlett et al. (1998).

Locality, habitats, weather and altitudes were recorded. Microhabitats were described for each site as vegetation types comprising of open deciduous dipterocarp forest (DDF). It consists of large clearings, seasonally inundated savannah grasslands, marshlands, seasonal and permanent pools, and interspersed patches of semi-evergreen forests and bamboo forests from medium to full canopy cover. Forest canopy and microhabitats were calculated into valid percent and cumulative percent, referring to percentage of each canopy and microhabitat that elongated tortoises preferred during the monitoring programme.

MARK version 8.0 was used to calculate the annual apparent survival rate of these nine released tortoises. LiveRecapture model of Mormack-Jolley Seber (Jolly, 1965 and Seber 1965) was used to analyse the annual apparent survival of the monitored individuals: the study period within a short monitoring timeframe and small number of studied animals (White, 1982). The animals, all adults, were divided into two groups (male and female). There were two periods of tracking in which the first 19 tracking occasions were done at a weekly manner and the last tracking occasion was done 10 months (40 weeks) after the 19th tracking occasion. Sixteen models were analysed and goodness of fit testing (GOF) method was also used to select the best model that best represents the data. 


\section{RESULTS}

\subsection{Rescue and relocation of turtles and tortoises}

\subsubsection{Rescued turtles and tortoises} Between February 2008 and January 2009 , four species of freshwater turtles (C. oldhamii, C. amboinensis, $H$. annandalii, and $A$. cartilaginea) and three species of terrestrial turtles and tortoises (C. galbinifrons, I. elongata, and $M$. impressa) were captured (Tab. I, Fig. 4, and Appendix I). A large number of $C$. oldhamii were captured $(n=205$, Fig. 4c), followed by I. elongata $(n=175$, Fig. 4f), C. amboinensis $(n=76$, Fig. 4b), $H$. annandalii $(n=15$, Fig. $4 d)$, and $A$. cartilaginea $(n=13$, Fig. 4a). It was also noticed that one shell specimen which was identified as Asian giant pond turtle (Heosemys grandis) by Emmett (2007) has not been found. However, 15 turtles that have been identified as $H$. annandalii were found and the team assumed that this species was firstly identified by Emmett (2007) as $H$. grandis. Furthermore, two other species, C. galbinifrons ( $n=5$, Fig. $4 \mathrm{e}$ ) and $M$. impressa $(n=1)$, were also found. All specimens of these species were caught within the inundated forest, except $M$. impressa that was handed over by the National Protected Area rangers who collected the specimen from a village outside of the reservoir. In general, the number of individuals trapped and released exceeded the number targeted in the relocation programme except for the Asiatic softshell turtle $A$. cartilaginea and the misidentified $H$. grandis (Tab. I and Fig. 4). Finally, one target freshwater species belonging to $S$. quadriocellata was not captured.

There were different trends of capture for the different species (Fig. 4). A large proportion of freshwater turtle species were captured during the first 6 months of the programme during the dry season (February to July 2008) just before the impoundment. This species belonged to $C$. oldhamii and $C$. amboinensis. In contrast, terrestrial species belonging to $C$. galbinifrons (Fig. $4 \mathrm{e}$ ) and $I$. elongata (Fig. 4f) were mainly caught during the wet season 2008 which corresponded to the impoundment period. At this time, most forest and grasslands were flooded with the creation of numerous small islands. This made the catch efforts easier since all tortoises were escaping from the water and moving to narrowly higher hills.

\subsubsection{Relocation of turtles and tortoises}

Three freshwater species (C. amboinensis, $C$. oldhamii, and $H$. annandalii) were released into artificial wetlands (Fig. 2 and Fig. 5) and especially into two wetlands (named A01 and A07; Fig. 5). These two wetlands were identified as the largest with suitable habitats for these species. They consisted of grassland, flooded shrub and deep water. Eight wetlands (named $\mathrm{A} 02$, $\mathrm{B} 02, \mathrm{~B} 03, \mathrm{~B} 06, \mathrm{~B} 07, \mathrm{~B} 08, \mathrm{~B} 14$, and $B 18)$ were chosen to release two species of freshwater turtles belonging to C. amboinensis (Fig. 5a) and C. oldhamii (Fig. 5b). These eight wetlands were only suitable for these species. They were similar in size and water depth with little grassland. They were 

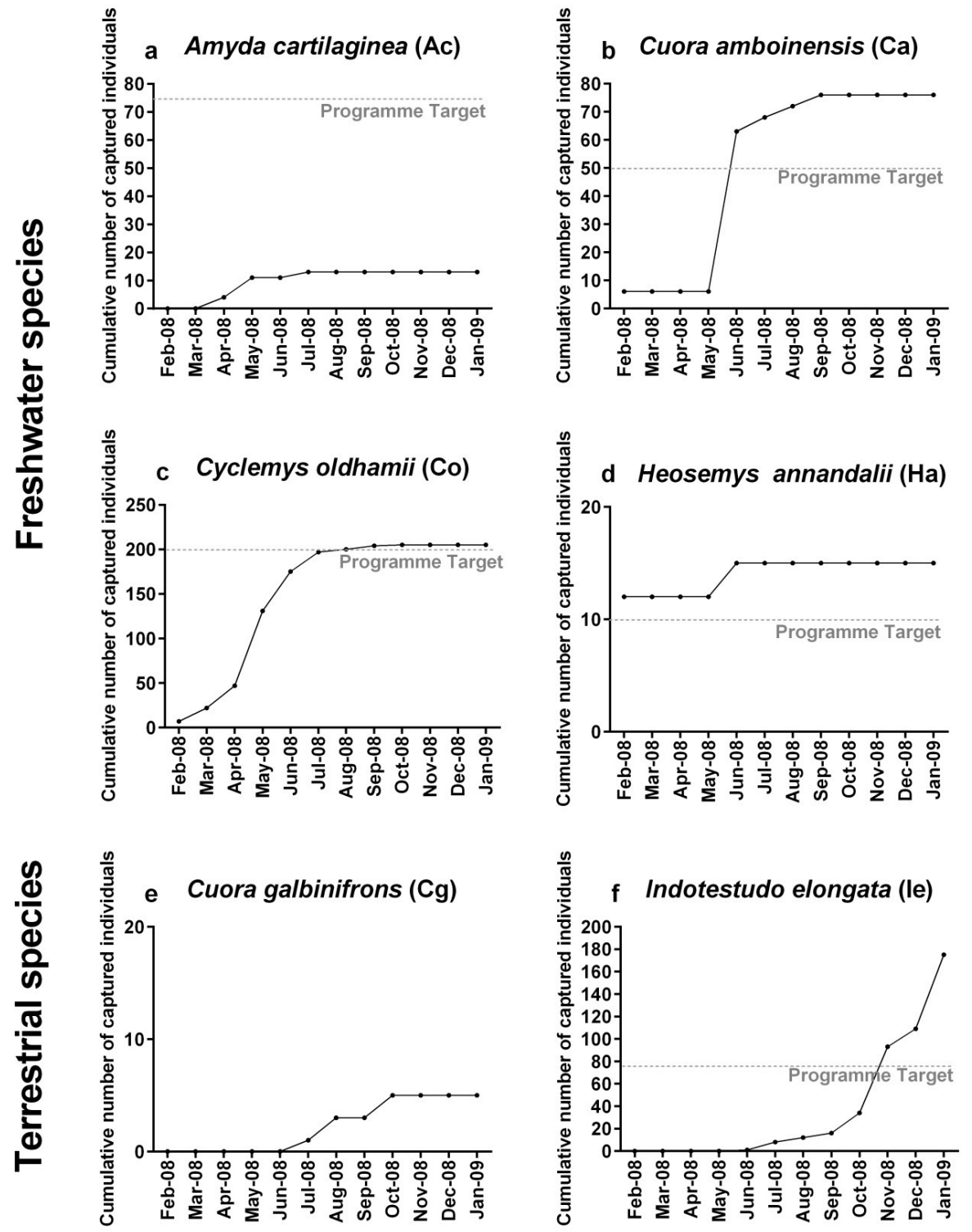

Fig. 4. Cumulative number of individuals captured of turtles and tortoises during the programme and targeted capture's for each species.

Fig. 4. Nombre cumulé de tortues capturées lors du programme et le nombre de captures ciblé pour chaque espèce. 

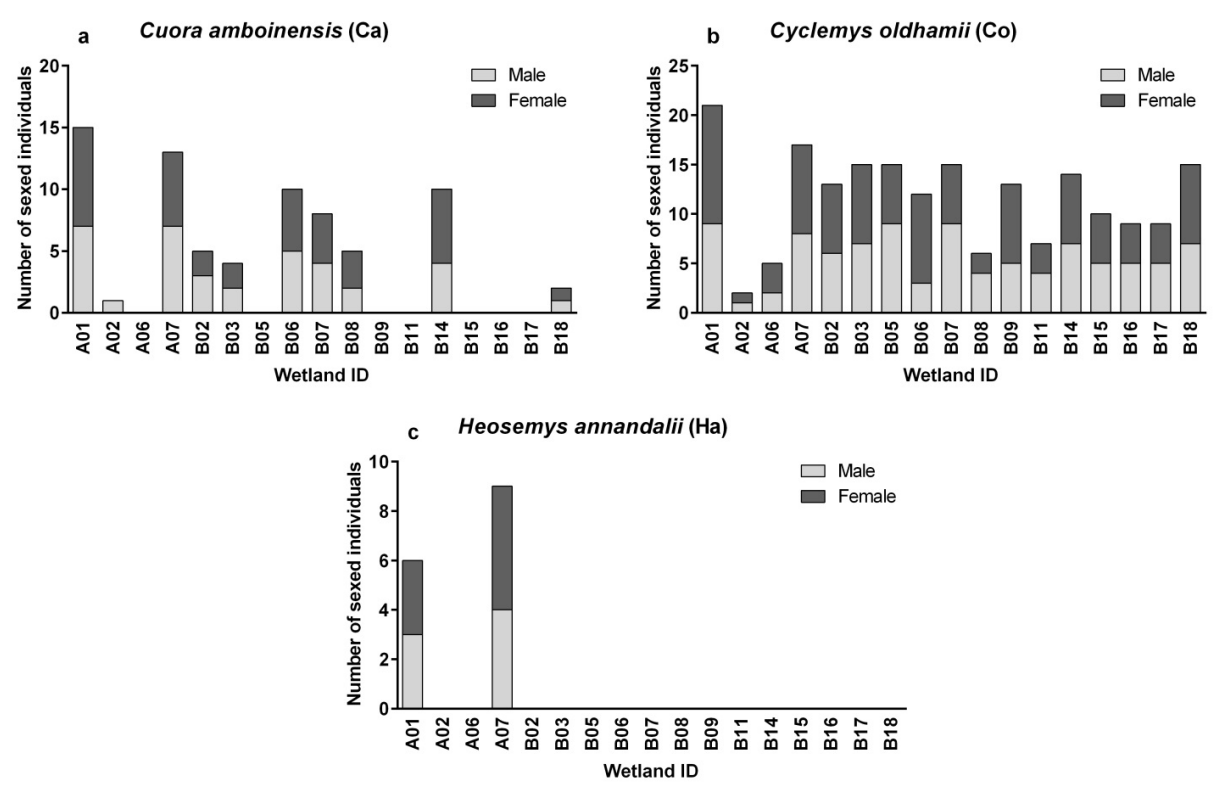

Fig. 5. Number of freshwater turtles (male and female) released into the different wetlands during the programme.

Fig. 5. Nombre de tortues d'eau douce (mâle et femelle) relâchées lors du programme au niveau de différentes zones humides.

not large enough to support other turtle or tortoise populations. The species C. oldhamii was released in other selected wetlands (named A06, B05, B09, B11, B15, B16, and B17) identified as suitable for the species during the early stage of the programme. For each wetland, an equivalent ratio between females and males belonging to each species was respected (Fig. 5) to offer more possibility to the population to be maintained.

Two terrestrial species were released at different habitats above the full supply level. Five $C$. galbinifrons and one $M$. impressa were released at evergreen forest along Nam Xot River where a mixture of evergreen forest and bamboo forest was identified.
Finally, thirteen individual of the freshwater species $A$. cartilaginea were released also in the Nam Xot River upstream (outside of the reservoir backwater effect) in deep pools.

\subsection{Monitoring programme of the Elongated Tortoise}

\subsubsection{Radio-tracking activities}

During the first 6 months of the monitoring, between August 2008 to January 2009 (reservoir impoundment period), there were 19 tracking activities and one tracking occasion during the second monitoring programme to follow the nine elongated tortoises. All nine 


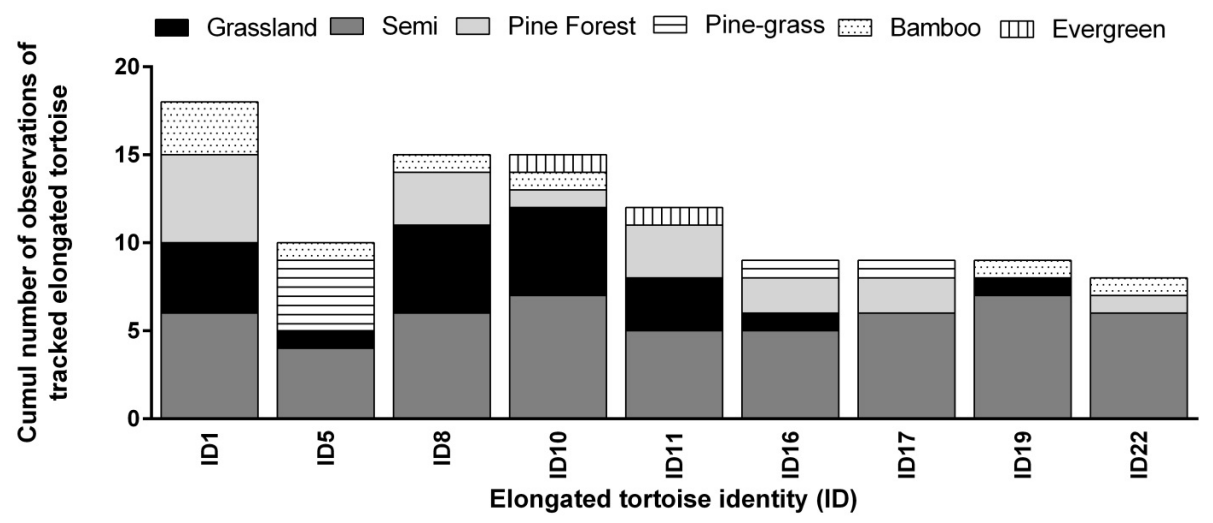

Fig. 6. Cumulated number of observation of each elongated tortoises found during the monitoring according to the microhabitat.

Fig. 6. Nombre cumulé de tortues à tête jaune trouvées lors du suivi en fonction du type de microhabitat.

individuals were re-captured using the receiver on all 19 occasions. Analysis showed that there was $100 \%$ survival rate of those all observed individuals released. Nonetheless, only four individuals of the observed nine tortoises (three females and one male) were retracked during the second phase of the monitoring which took place in November and December 2009 (14 months after the initial release in August 2008 and ten months after the end of the first monitoring in January 2009). The overall annual apparent survival rate at this stage was $47 \%$ with female $(62 \%)$ has higher survival rate than male (32\%).

\subsubsection{Use of microhabitat and behaviour}

The monitoring showed that the elongated tortoise species inhabits in different types of habitats, ranging from semi-evergreen forest, grassland, pine forest mixed with grass understory, bamboo, and evergreen forest that is close to the grassland and semi-evergreen forest (Fig. 6). Furthermore, this species preferred to stay more often in semi-evergreen forest (between 33\% and $78 \%$ of individual's number of observation; Fig. 6) where there were mixtures between grass, bamboo, and pine trees. The study also found that this species inhabits in rather cold areas with ambient minimum temperatures of $2.2^{\circ} \mathrm{C}$ and maximum temperatures not exceeding $26^{\circ} \mathrm{C}$ and constant humidity values around $100 \%$.

However, this behaviour depended largely on different times of the year (Fig. 7). Tracking analysis showed that grassland and bamboo were the most common places for I. elongata to hide during August and September (around $55 \%$ of observations for grassland, 28 $33 \%$ of observations for bamboo). After the rainy season, the species tended to 


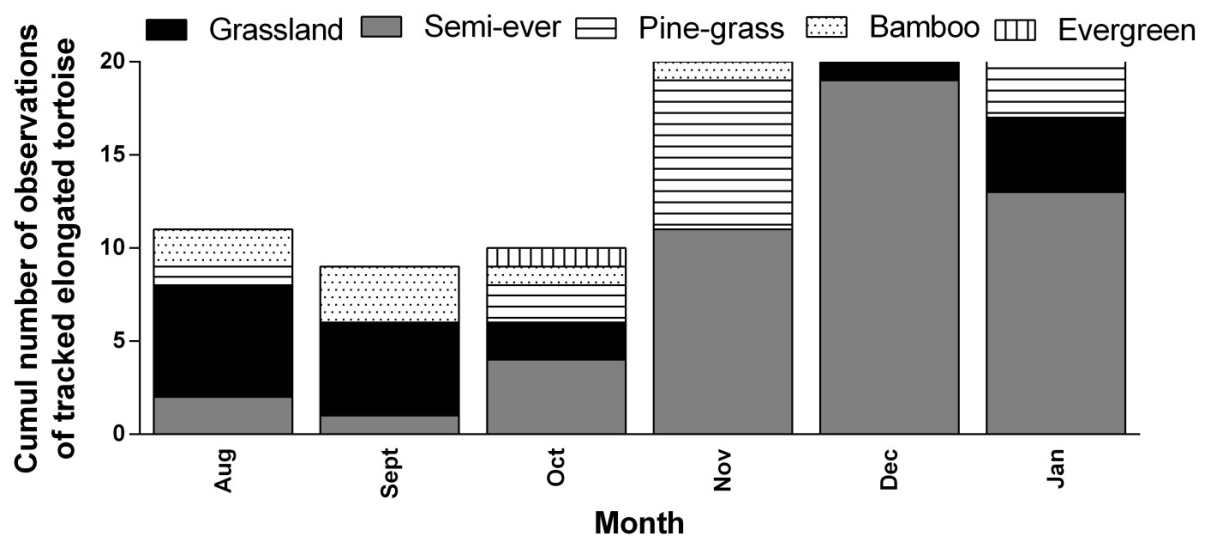

Fig. 7. Cumulated number of elongated tortoises found during the monitoring according to the microhabitat and different months.

Fig. 7. Nombre cumulé de tortues à tête jaune trouvées lors du suivi en fonction du type de microhabitat et de différents mois.

inhabit very often in habitats of semievergreen forest $(40-65 \%$ of the observations) and pine forest with grassland, occasionally moving to evergreen forest. The canopy above the micro-habitats was not important in relation to the hiding places used by I. elongata. However, open canopy (46.1\%, Tab. II) was found to be the most preferred habitat during the wet season. At the relocated sites, there were more open areas than forests. These open areas were commonly associated to the presence of tortoises. In the warm time of the year when grassland is always burnt, I. elongata preferred to inhabit under full cover canopy $(25.8 \%)$ and semi-cover canopy (28.1\%) (Tab. II and Fig. 7).

l. elongata moved from one place to another every few days for foraging. The finding showed that this species spent $99.1 \%$ (88 out of 89 tracking times from all 9 individuals) hiding during the day time in grass bushes, under bamboo shrubs, under leaf litters, and underneath logs (Tab. II). They were sometimes found hiding in grasses with high sunlight which is called basking behaviour. I. elongata mostly stayed in grasses at open areas most of the time except during the dry season, when they moved to hide in the shade of the forest. This activity always occurred in the driest time of the year when grasses were dead and burnt. Only $0.9 \%$ of one individual ( 1 time movement) was seen moving during the day time (Tab. II). In the dry season, they spent large amounts of time resting in the holes underground, in tree burrows, under bamboo shrub, under leaf litter or tree root. However, grassland, bamboo shrub, and tree logs are places this species prefers the most with $41.6 \%, 23.6 \%$, and $10.1 \%$ respectively (Tab. III). This kind of rest helped them maintain the body temperature, humidity, and protection from hunting due to increased invisibility. 
Table II. Canopy above microhabitats (in \%) and behaviour of the elongated tortoise during the monitoring programme of the species.

Tableau II. Canopée au-dessus des microhabitats (en \%) et comportement des tortues à tête jaune lors du programme de suivi de l'espèce.

\begin{tabular}{|c|c|c|c|c|c|}
\hline & Types & Frequency & $\begin{array}{c}\text { Valid } \\
\text { percent }\end{array}$ & $\begin{array}{c}\text { Cumulative } \\
\text { percent }\end{array}$ & Observed time \\
\hline \multirow{4}{*}{ Canopy } & Open & 41 & 46.1 & 71.9 & Aug-Oct \\
\cline { 2 - 6 } & Full cover & 23 & 25.8 & 25.8 & Nov-Jan \\
\cline { 2 - 6 } & Semi cover & 25 & 28.1 & 100 & Nov-Jan \\
\cline { 2 - 6 } & Total & 89 & 100 & & \\
\hline \multirow{3}{*}{ Behaviour } & Hiding & 88 & 99.1 & 99.1 & Day time \\
\cline { 2 - 6 } & Moving & 1 & 0.9 & 100 & Day time \\
\cline { 2 - 6 } & Total & 89 & 100 & & \\
\hline
\end{tabular}

Table III. Types of microhabitat preference for elongated tortoise (\%) during the monitoring programme. Tableau III. Préférence des microhabitats (\%) de la tortue à tête jaune pendant le programme de suivi.

\begin{tabular}{|c|c|c|c|}
\hline Micro-habitats & Frequency & Valid percent & Cumulative percent \\
\hline Under grass & 37 & 41.6 & 41.6 \\
\hline Under bamboo shrub & 21 & 23.6 & 65.2 \\
\hline Under log & 9 & 10.1 & 75.3 \\
\hline Under grass shrub & 6 & 6.7 & 82 \\
\hline Under leaf litters & 6 & 6.7 & 88.7 \\
\hline In hole & 3 & 3.4 & 92.1 \\
\hline Under dead tree branches & 3 & 3.4 & 95.5 \\
\hline In grass & 2 & 2.3 & 97.8 \\
\hline Under small plants & 1 & 1.1 & 98.9 \\
\hline Under tree roots & 1 & 1.1 & 100 \\
\hline Total & $\mathbf{8 9}$ & $\mathbf{1 0 0 . 0}$ & \\
\hline
\end{tabular}

Finally, during the second phase of monitoring, weight showed normal values with a slight increase among the four tortoises re-tracked and recaptured (Tab. IV).

\section{DISCUSSION}

\subsection{Rescue and relocation programme}

The rescue and relocation programme is assumed to have been a successful conservation towards freshwater turtles and tortoises in Nakai protected area (NPA). This was due to the fact that a large proportion of each species was captured and relocated into new built or natural habitats in the NPA. In total, 296 freshwater turtles were released into artificial wetlands identified as suitable habitats for each species in terms of wetland size, water quality and vegetation.

Even though the number of $A$. cartilaginea captured did not reach the 
Table IV. Weight measurement $(\mathrm{kg})$ of re-captured elongated tortoise. Tableau IV. Poids $(\mathrm{kg})$ des tortues à tête jaune recapturées.

\begin{tabular}{|c|c|c|c|c|}
\hline Species & Individual ID & $\begin{array}{c}\text { Initial weight } \\
\text { (kg) }\end{array}$ & $\begin{array}{c}\text { Weight after recapture } \\
(\mathbf{k g})\end{array}$ & Comparison \\
\hline \multirow{3}{*}{$\begin{array}{c}\text { Indotestudo } \\
\text { elongata }\end{array}$} & le 1 & 1.60 & 1.66 & \multirow{3}{*}{$\begin{array}{c}\text { Slight increase or } \\
\text { stable in weight }\end{array}$} \\
\cline { 2 - 4 } & le 2 & 1.90 & 2.29 & \\
\cline { 2 - 5 } & le 3 & 1.80 & 1.82 & \\
\cline { 2 - 4 } & le 4 & 1.67 & 1.70 & \\
\hline
\end{tabular}

targeted numbers (Tab. I), the programme allowed rescuing a large number of other species during the reservoir impoundment. For some species, the number of rescued and relocated individuals was over the programme targeted number e.g. C. oldhamii (205 rescued individuals vs. 200 targeted number), C. amboinensis (76 rescued individuals vs. 50 targeted number), or l. elongata (175 rescued and relocated individuals from a proposed target of 75$)$. I. elongata were released into new natural habitats in the NPA, where there was plenty of vegetation for this species to strive for their new population establishment.

Apart from selected species for relocation, other species were also rescued from the reservoir such as $C$. galbinifrons, $M$. impressa, and $H$. annandalii. The species $C$. galbinifrons, that was confirmed to be present at a high altitude (e.g. $900 \mathrm{~m}$ asl) by Stuart \& Parham (2003), was found in a lower elevation at just around $500 \mathrm{~m}$ asl. The species $H$. annandalii was initially identified as $H$. grandis by Emmett (2007) through one shell specimen in a village. According to the potential misidentification issue during the baseline, the target of 10 individuals of this species could be considered as reached. A small number of $A$. cartilaginea were caught during the programme. This low number might be linked to hunting activities in the area. Lack of trapping effort and difficulties in catching this species might also have contributed to have a lower number caught. In contrast, one freshwater species belonging to $S$. quadriocella was not captured during the programme. This could be explained by the fact that the population of this species was reduced in this geographic area and/or this could be also linked to a lack in the effort of trapping time within the wrong season. The capture according to the season appeared to be an essential component of the monitoring. The monitoring showed that freshwater species were mainly caught during the dry season before the impoundment, when there is less water in trapping locations whereas terrestrial species were caught during the wet season (impoundment) when they tried to escape from water and their habitats were narrowed down by reservoir water.

For relocated species, each released site proportionally included males and females, juveniles and adults to ensure future breeding success. It can be assumed these species will be able to establish a new population in relocated site. For instance, I. elongata population relocated in the 
NPA are expected to re-establish in this area by covering large areas of forest habitats. Nevertheless, the success for future conservation will not only depend on a new establishment of population within different wetland habitats with new population able to breed for long generations to come but also on external threats such as poaching or illegal hunting.

\subsection{Monitoring programme of the elongated tortoise}

Of 175 released elongated tortoises, nine of them were fitted with transmitters for monitoring at the same time during the rescue and relocation programme. Within the first monitoring phase, all nine individuals were observed alive- indicating a $100 \%$ survival rate of the released animals. A second phase of monitoring on this species was conducted 14 months after the initial release in August 2008 or 10 months after the end of the first monitoring in January 2009. Only four individuals (three females and one male) were re-tracked and found alive in their new habitats. Their annual survival rate has dramatically dropped to an overall of $47 \%$ of which male and female have their survival rate of $32 \%$ and $61 \%$ respectively. The other five animals may have migrated out of the study area or may have lost their transmitters. While the annual survival rate of similar tortoise species from previous well-studied literature within natural population ranges from 88 to $96 \%$ (Hailey, 1990, 2000; Willemsen \& Hailey, 2002), translocated wild tortoises have a slightly lower survival rate ranging from 70 to $81 \%$ (Cook et al., 1978; Lohoefener \& Lohmeier, 1986; Guyot \& Clobert, 1997). However, in most cases, the annual survival rate of translocated and rehabilitated tortoises will always be much smaller than those of wild tortoises (Lhoefener \& Lohmeier, 1986). For instance, a five-month monitoring study using the same method to study the annual survival rate of $I$. elongata in the Kulen Promtep Wildlife Sanctuary in Cambodia by Ihlow et al. (2014) found that there was $76 \%$ annual survival rate within this species. This rate of $76 \%$ is lower than the results found in these Nam Theun 2 radiotracking activities. For instance, having a $100 \%$ annual survival rate (all nine individuals were re-tracked) within a similar period (six months, first phase of the monitoring) and showed an activity in their new habitat, this result shows a great success of this species establishment in their new habitat. However, only four of the nine individuals were retracked. This annual survival rate then declined 10 months after the end of relocation programme (14 months after the initial release in August 2008) to only $47 \%$ (four individuals found) within NT2 Project area. These results could be explained by the fact that there may have been an error of the attached transmitters of the five lost tortoises. Even so, this finding suggested the potential threat in the area such as illegal hunting. There was no evidence to suggest that there are problems with new establishment. This hypothesis in the analysis was strengthened by the fact that all recaptured tortoises showed a slight increase of weight which is indicating the good establishment of their healthy population. 
The study found that $I$. elongata preferred to inhabit at different vegetable types of microhabitats. During the wet season the species tended to stay in places with a more open canopy while in the dry season they preferred to stay in places with a full cover canopy, ranging from semi to evergreen forests and dense bamboo forests. The different forest types made micro-habitats diverse in humidity, daily patterns in temperature, visibility, and food availability. In dry season, evergreen forest and semi evergreen forest were the preferred habitats of $I$. elongata because they provided higher humidity, lower temperature, and more invisibility whereas open grassland and other habitats may be too hot and too dry during the day time. More specifically, grasslands and bamboo forests are the most common places this species preferred. This finding was consistent with the result provided by Ihlow et al. (2014), showing preferred habitat of this species at savannah (grassland), bamboo, and semi-evergreen forests. Significantly, this study also revealed that this species was commonly inactive during the day time in which almost $100 \%$ of them hidden during this period, especially under fallen trees and in holes.

At the end of the monitoring programme, there was enough evidence that $I$. elongata was still abundant in the NPA. With the large proportion of individuals released and the number of individuals re-tracked during the monitoring programme, it is extremely likely that this species will establish their population for years and may become even greater in population if proper conservation measures are implemented in this area.

\subsection{Evaluation of the rescue and relocation programme}

Although, different literature suggested little success rate has been found within reptiles such as Dodd \& Seigel (1991), other studies found that relocation programme has proved to be significant for population establishment (Ashton \& Burke, 2007; Ihlow et al., 2014). Germano \& Bishop (2009) suggested that success and failure rates of relocation were dependent on the taxonomic class (amphibians or reptiles) and conservation efforts within responsible institutions. There is an increase rate of reptile and amphibian translocations from the past 15 years, accounted for a $41 \%$ success rate (Germano \& Bishop, 2009) compared to only $19 \%$ in 1991 (Dodd \& Seigel, 1991). The result from the rescue programme in the Nam Theun 2 area provided empirical evidence that relocation and translocation programmes for turtle species (freshwater and terrestrial species) could be significantly a success especially in area where their natural habitats were deteriorated by the reservoir creation. This programme has rescued a large number of freshwater and terrestrial turtles and tortoises from the inundated reservoir. However, there were important improvements needed to be considered and implemented to demonstrate the overall success of this relocation programme. Many factors can contribute to have both positive and negative impacts on establishment of released species such as conservation efforts in the area, threats, and errors from monitoring equipment. Monitoring programme always takes years to find accurate success (Germano \& Bishop, 
2009) and long-term monitoring is important for the NT2 turtle project. Therefore, another well-designed monitoring programme for elongated tortoises is needed in the future.

\subsection{Threats}

During rescue, relocation, and monitoring programmes, some threats have been identified that might lead to the reduction of all freshwater turtle and tortoise species in the area. These threats included illegal hunting by local people who used their skilled dogs to sniff out concealed turtles and tortoises. The team observed, on a number of occasions, that people always brought their dogs with them whenever they went fishing, logging, and hunting. Other threats to tortoises are forest and grassland fires during the dry season (slash and burn practice) between November and April. Although some elongated tortoises might be able to escape from a fast grassland fire through their strong protective shell, they would be unable to hide from humans when there is no more grass and they will be easily seen by hunters. As cited by various literatures (e.g. Ihlow et al., 2014), this species can well establish within a new environment when there is strong enforcement.

\section{ACKNOWLEDGEMENT:}

This research has been conducted in the Reservoir area of Nam Theun 2 Power Company in Lao PDR whose Shareholders are Électricité de France, Lao Holding State Enterprise and Electricity Generating Public Company Limited of Thailand.
The author would like to thank a number of Cambodian researchers who were involved in the programme including Koulang Chey, Yoeung Sun, Sokhorn Kheng, and Chamnan Kim. A special thanks also go to various Lao people who assisted during the programme including Mr. Hongkham, Mr. Khampheu, Mr. Bounthong, Mr. Don Suvandee, and staff from the wildlife rescue programme, staff from the former Environmental Monitoring Office of NTPC, Stuart Gillon and especially Mr. Souliphone Phommachan. The author would like also to thank Mr. Liankham Payasane (NTPC-GIS team), the NTPC logistic team and their useful boat drivers and Mr. Paul Dumbrell who reviewed and improved this version of the manuscript as a native English speaker. Finally authors would like to thank the reviewers for their useful comments which helped for the improvement of the manuscript.

\section{REFERENCES}

Alho C.J., 2011. Environmental effects of hydropower reservoirs on wild mammals and freshwater turtles in Amazonia: a review. Oecologia Australis 15(3) : 593-604.

Ashton K.G. \& Burke R.L., 2007. Long Term Retention of a Relocated Population of Gopher Tortoises. J. Wildlife Manage. 71(3) : 783-787.

Bryan S., 1999. Amphibians and Reptiles. In: Duckworth J.W., R.E. Salter \& K. Khounboline (Eds.), Wildlife in Lao PDR: 1999 Status Report. (Ed.). Vientiane: IUCN- The World Conservation Union/ Wildlife Conservation Society / Centre for Protected Areas and Watershed Management, 43-67. 
Buhlmann K.A., Akre T.S., Iverson J.B., Karapatakis D., Mittermeier R.A., Georges A., Rhodin A., Van Dijk P.P. \& Gibbons J.W., 2009. A global analysis of tortoise and freshwater turtle distributions with identification of priority conservation areas. J. Inform. 8 (2) : 116-149.

Cablk M.E. \& Heaton J.S., 2006. Accuracy and reliability of dogs in surveying for desert tortoise (Gopherus agassizii). Ecol. Appl. 16(5) : 1926-1935.

Chanudet V., Guédant P., Rode W., Guérin F., Serça D., Deshmukh C. \& Descloux S. Evolution of the physico-chemical water quality in the Nam Theun 2 Reservoir for the first 5 years after impoundment. Hydroécol. Appl. 19 (same issue).

Cook J., Weber A. \& Stewart G., 1978. Survival of captive tortoises released in California. Proceedings of the Desert Tortoise Council 1977 Symposium 130135.

Descloux S., Guédant P., Phommachanh D. \& Luthi R. Main features of the Nam Theun 2 hydroelectric project (Lao PDR) and the associated environmental monitoring programme. Hydroécol. Appl. 19 (same issue).

Dodd Jr C.K. \& Seigel R.A., 1991. Relocation, repatriation, and translocation of amphibians and reptiles: are they conservation strategies that work? Herpetologica 47 : 336-350.

Dudgeon D., Arthington A.H., Gessner M.O., Kawabata Z.I., Knowler D.J., Lévêque C., Naiman R.J., PrieurRichard A.H., Soto D., Stiassny M.L.J. \& Sullivan C.A., 2006. Freshwater biodiversity: importance, threats, status and conservation challenges. Biol. Rev. 81(2) : 163-182.

Emmett D., 2007. Assessment of likely impacts of the NT2 project on the herpetofauna of the Nakai Plateau, and possibilities for mitigation. Dersu \& Associates, $126 \mathrm{p}$.
Farnsworth S.D. \& Seigel R.A., 2013. Responses, Movements, and Survival of Relocated Box Turtles During Construction of the Intercounty Connector Highway in Maryland. Transportation Research Record: Journal of the Transportation Research Board of the National Academies, Washington DC, 2362 : 1-8.

Frazer N.B., Gibbons J.W. \& Owens T.J., 1990. Turtle trapping: preliminary tests of conventional wisdom. Copeia : 11501152.

Germano J.M. \& Bishop P.J., 2009. Suitability of amphibians and reptiles for translocation. Conserv. Biol. 23(1) : 7-15.

Goodlett T., Goodlett G. \& Hamilton P., 1998. Review of radio transmitter attachment techniques for turtle research and recommendations for improvement. Herpetol. Rev. 50(26) : 29.

Guyot G. \& Clobert J., 1997. Conservation measures for a population of Hermann's tortoise Testudo hermanni in southern France bisected by a major highway. Biol. Conserv. 79(2) : 251-256.

Hailey A., 1990. Adult survival and recruitment and the explanation of an uneven sex ratio in a tortoise population. Can. J. Zool. 68(3) : 547-555.

Hailey A., 2000. The effects of fire and mechanical habitat destruction on survival of the tortoise Testudo hermanni in northern Greece. Biol. Conserv. 92(3) : 321-333.

Ihlow F., Rödder D., Bochynek T., Sothanin S., Handschuh M. \& Böhme W., 2014. Reinforcement as a conservation toolassessing site fidelity and movement of the endangered elongated tortoise Indotestudo elongata (Blyth, 1854). J. Nat. Hist:: 1-13.

Jolly G.M., 1965. Explicit estimates from capture-recapture data with both death and immigration-stochastic model. Biometrika : 225-247. 
Le M., 2007. Conservation of turtles in Vietnam: a survey of Cat Tien National Park. Oryx 41 : 544-547.

Lohoefener R. \& Lohmeier L., 1986. Experiments with gopher tortoise (Gopherus polyphemus) relocation in southern Mississippi. Herpetol. Rev. 17 : 37-40.

McAllister D., Craig J.F., Davidson N., Delany S. \& Seddon M., 2001. Biodiversity impacts of large dams. Background Paper 1. International Union for Conservation of Nature and Natural Resources and the United Nations Environmental Programme, $68 \mathrm{p}$.

MRC, 2010. State of the Basin Report 2010. Mekong River Commission, Vientiane, Lao PDR, $123 \mathrm{p}$.

Santucci Jr V.J., Gephard S.R. \& Pescitelli S.M., 2005. Effects of multiple low-head dams on fish, macroinvertebrates, habitat, and water quality in the Fox River, Illinois. N. Am. J. Fisheries Manage. 25(3) : 975-992.

Seber G.A., 1965. A note on the multiplerecapture census. Biometrika: 249-259.

Som S., 2009. Turtle Conservation Program Nam Theun 2 Hydroelectric Project. Internal report of the Nam Theun 2 Power Company, $33 \mathrm{p}$.

Som S., Chey K. \& Sun Y., 2005. Tortoise and Freshwater Turtle Conservation in the Cardamom Mountains, Cambodia. Cambodian Turtle Conservation Project, Phnom Penh, Kingdom of Cambodia, $104 \mathrm{p}$.

Streicher U. The Wildlife Rescue Programme of the Nam Theun 2 Hydropower Project (Lao PDR). Hydroécol. Appl. 19 (same issue).

Stuart B. \& Thorbiarnarson J., 2003. Biological prioritization of Asian countries for turtle conservation. Chelonian Conserv. Biol. 4(3) : 642-647.

Stuart B., van Dijk P.P. \& Hendrie D., 2001. Photographic guide to the turtles of Thailand, Laos, Vietnam and Cambodia. Wildlife Conservation Society, New York, $84 \mathrm{p}$.

Stuart B.L. \& Platt S.G., 2004. Recent records of turtles and tortoises from Laos, Cambodia, and Vietnam. Asiatic Herpetol. Res. 10(2) : 129-150.

Stuart B.L. \& Timmins R.J., 2000. Conservation status and trade of turtles in Laos. Chelonian Res. Monogr. 2 : 58-62.

Stuart B.L., Hallam C.D., Sayavong S., Nanthavong C., Sayaleng S., Vongsa O. \& Robichaud W.G., 2011. Two additions to the Turtle Fauna of Laos. Chelonian Conserv. Biol. 10(1) : 113-116.

Stuart L.B. \& Parham F.J., 2003. Molecular phylogeny of the critically endangered Indochinese box turtle (Cuora galbinifrons). Mol. Phylogenet. Evol. 31 : 164177.

Turtle Conservation Fund, 2002. A global action plan for conservation of tortoises and freshwater turtles. Strategy and funding prospectus, 2007, 30.

White G.C., 1982. Capture-recapture and removal methods for sampling closed populations: Los Alamos National Laboratory, $235 \mathrm{p}$.

Willemsen R.E. \& Hailey A., 2002. Body mass condition in Greek tortoises: regional and interspecific variation. Herpetol. J. 12(3) : 105-114.

Zhou Z. \& Jiang Z., 2008. Characteristics and Risk Assessment of International Trade in Tortoises and Freshwater Turtles in China. Chelonian Conserv. Biol. 7(1) : 28-36. 
Appendix 1 - Species found during the turtle and tortoise rescue and monitoring programme (photography by S. Som).

Annexe 1 - Espèces trouvées lors du programme de sauvetage et du suivi des tortues (photographies de S. Som).
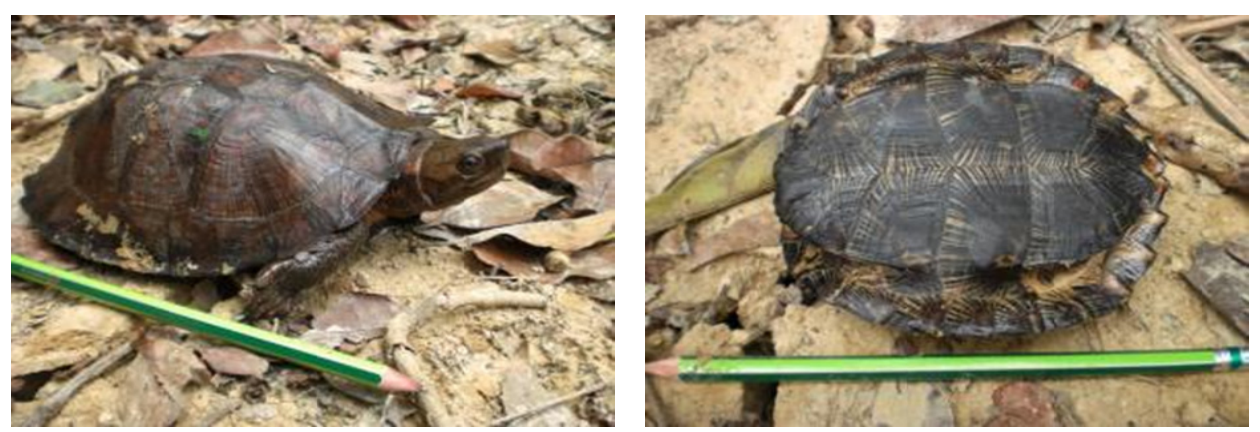

1 - Carapace and plastron of C. oldhamii.

1 - Carapace et plastron de C. oldhamii.
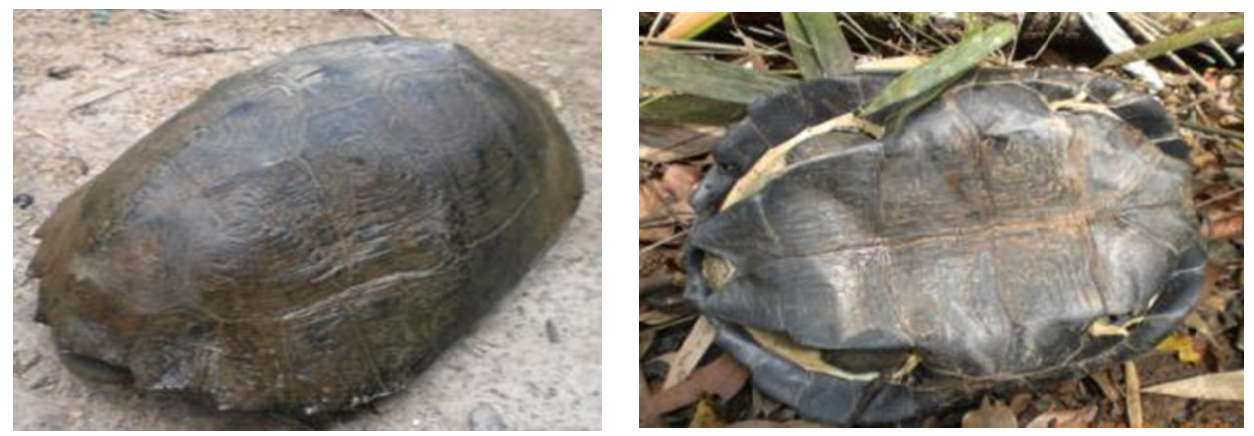

2 - Carapace and plastron of $H$. annandalii.

2 - Carapace et plastron de $H$. annandalii.
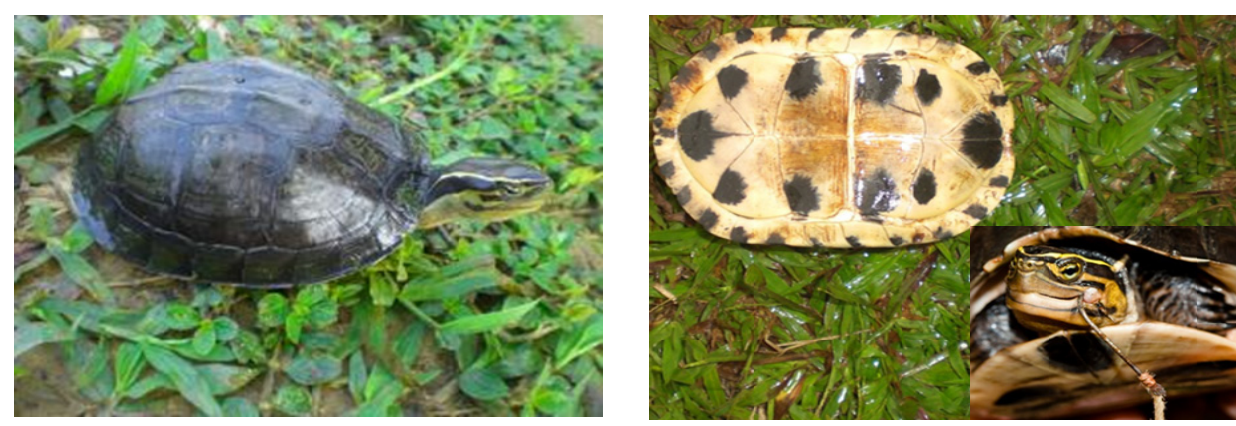

3 - Carapace and plastron of C. amboinensis - Picture of one specimen found with a fishing hook. 3 - Carapace et plastron de $C$. amboinensis - Photo d'un spécimen trouvé avec un hameçon. 

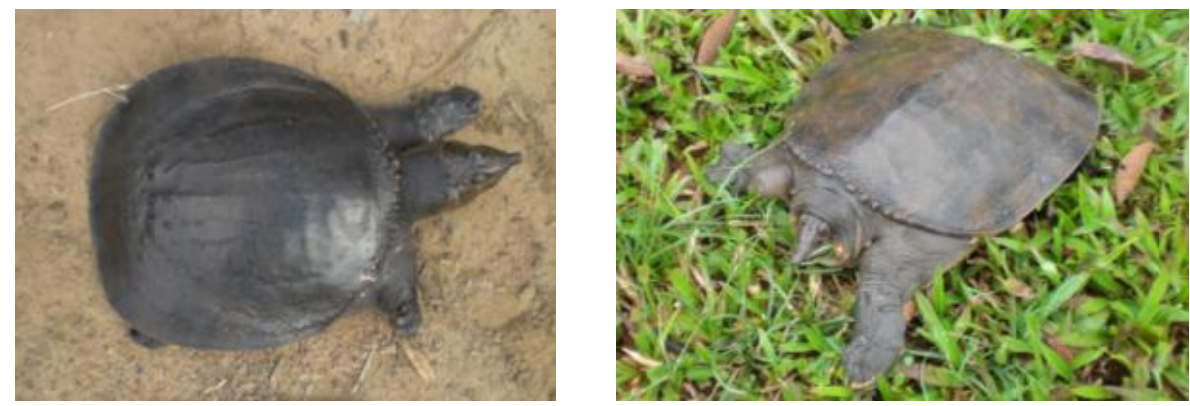

4 - Picture of $A$. cartilaginea.

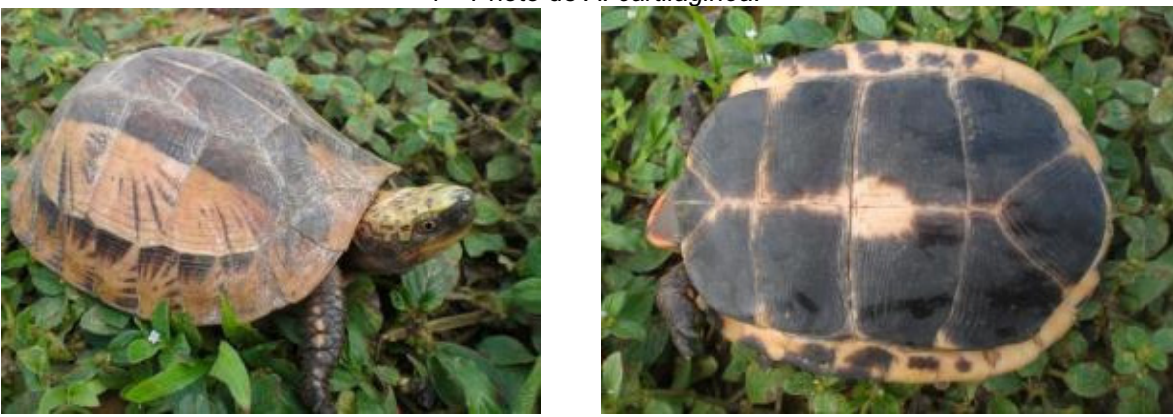

5 - Carapace and plastron of C. galbinifrons.

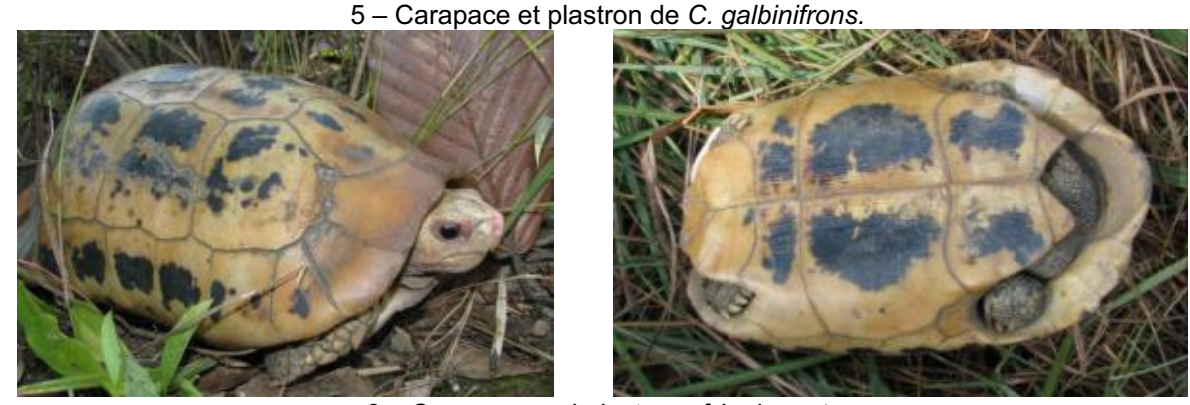

6 - Carapace and plastron of I. elongata.

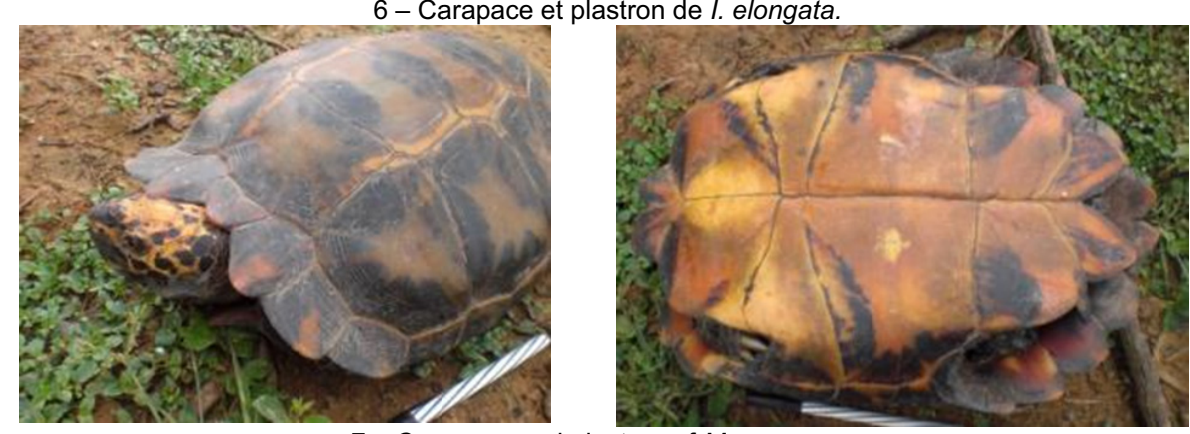

7 - Carapace and plastron of $M$. empressa

7 - Carapace et plastron de M. empressa. 